\title{
THE ROLE OF INSTAGRAM INFLUENCERS AS A SOURCE OF FASHION INFORMATION
}

\section{Tomovska Elena}

Faculty of Technology and Metallurgy,

University "Ss. Cyril and Methodius", Skopje, Nort Macedonia,

e-mail: etomovska@tmf.ukim.edu.mk
Professional paper

UDC: 316.35:687:391

doi: $10.5937 /$ tekstind 2004058 T

\begin{abstract}
Social media has become a powerful communicating tool for the fashion industry, providing an instant, democratic, user-generated dissemination of fashion trends, particularly with the younger generations. Image-centred social media, such as Instagram are particularly well adopted for fashion communication. This research aims to investigate the role of Instagram on the dissemination of fashion trends amongst Generation $Z$. The research used an electronic questionnaire distributed to 120 participants, aged 16 to 23 years. A commercially available tool for measuring the reach of global and local fashion influencers was used to comprise a list of influencers used in the research. Cluster analysis was used to identify Instagram influencers impacting fashion and the use of Instagram as a fashion information channel.
\end{abstract}

Keywords: fashion opinion leaders, social media, Instagram.

\section{ULOGA INSTAGRM INFUENSERA KAO IZVORA MODNIH INFORMACIJA}

Apstract: Društvene mreže su postale moćan komunikacioni alat za modnu industriju, obezbeđujući trenutno, demokratsko, korisnički generisano širenje modnih trendova, posebno među mlađim generacijama. Društvene mreže koje koriste sliku, kao što je Instagram su vrlo dobro prilagođene za komunikaciju kad je reč o modi. Ovo istraživanje ima za cilj da ispita ulogu Instagrama po pitanju širenja modnih trendova među generacijom Z. Istraživanje koristi elektronski upitnik dostavljen do 120 učesnika, u dobi od 16 do 23 godina. Komercijalno dostupan alat za merenje uticaja globalnih i lokalnih modnih influensera je upotrebljena za formiranje liste influensera koja se koristi u istraživanju. Klaster analizom identifikovani su Instagram influenseri koji utiču na modu i primena Instagrama kao kanala za informacije o modi.

Klučne reči: lideri modnog mišljenja, društvene mreže, Instagram.

\section{INTRODUCTION}

As a social and cultural phenomenon, the fashion sector plays an important role in the contemporary economy. The advent of the Internet, and the Web 2.0 in particular, has changed both the way consumers buy and how they think [1,2]. The online environment is an efficient tool in all the stages of the buyer decision making process - information gathering, as well as shopping [3].
Developed in 2010 Instagram defines itself as "a fun and quirky way to share your life with friends through a series of pictures. Snap a photo with your mobile phone, then choose a filter to transform the image into a memory to keep around forever" [4]. The visual form of the presented content is particularly well adapted to the fashion industry. With an audience of over 1 billion active users [5] it offers fashion marketers an unprecedented access to consumers. 
The core group of Instagram users comprises of 18 to 34-year-olds, encompassing two generational cohorts: generation $Y$ (born before the year 2000) and generation $Z$ (born after the year 2000). While the digital fashion experiences of generation $Y$ have been explored [6,7], little information can be found on the upcoming generation $Z$.

The phenomenon of fashion diffusion is a wellknown concept in fashion theory [8]. The model of diffusion of fashion innovation, as described by Rogers [9], implies that fashion spreads gradually from the fashion innovators to early adopters, early majority, late majority and laggards. An important role in the diffusion of fashion is attributed to fashion opinion leaders. Opinion leadership has been defined in many ways, yet the concept is consistently associated with influence [10] and information sharing [11]. With that in mind opinion leaders are persons who are regarded by a group, or by other people, as having expertise and knowledge and who are considered as appropriate sources of information and advice, while having an unequal amount of influence on the decisions of others. In the world of social media, the influence of opinion leaders takes various forms, covered under the portmanteaux of "influencer". On the one hand there are the traditional opinion leaders in the face of celebrities. Social media has transformed the celebrities' ability to manage their images online and to connect directly with their consumers, producing human brands valuable in product endorsement [12]. On the other hand, new players in the face of fashion bloggers have occurred. Bloggers develop and maintain an image and relationship with their audience which often translates into an 'expert' or 'celebrity' status amongst readers, creating a human brand through affective-based networks [13]. They are one form of micro-celebrity who accumulates a following on blogs and social media through the textual and visual narration of their personal, everyday lives, upon which paid advertorials for products and services are premised [14]. The new type of opinion leader with crowds of online followers has been called citizen influencers by some researchers [15]. As the main characteristic of social networks is that they tend to be viral and of immediate response, influencers can contribute towards fast and global dissemination of fashion trends. Even if mass fashion dissemination is not a new concept [8], this new possibility for instant communication opens new alleys for consumers and marketers alike. From the aspect of consumers, access to information on fashionable items can make them more fashion forward.
Although the industry has widely adopted this particular social media tool, the academic research on Instagram, as a fashion communication tool, lags far behind. The majority of the studies analysed brands' strategic use of Instagram, rather than focusing in the consumers' perception of the marketing information. Social media and Instagram have been investigated as a tool for disseminating fashion trends, by both luxury $[16,17]$, and high street brands $[2,18]$.

The purpose of this research is to investigate the influence of Instagram on the acceptance of fashion trends by Generation Z.

\section{METHODOLOGY}

Using a convenience sampling method data was gathered by surveying female university students. The argument that a sample relevant to the universe of a theory could constitute a test of that theory supports employing a convenience sample, rather than having a random sample from the total population of young people [19]. Thus, the target population of the study were young consumers who are currently active users of Instagram. Research has indicated that core users of Instagram with high frequency of usage are 18 to 23-year-olds and that women use Instagram more than men [20]. In addition, women are consistently found to be heavier consumers of clothing [21].

An online questionnaire was distributed in September 2018. Links to the questionnaire were shared on student study groups on social media at the largest N. Macedonian University, Ss Cyril and Methodius - Skopje. As a state university, the demography of students of the university is fairly representative of the national youth population. Out of 120 questionnaires distributed, 97 useful, fully answered, questionnaires were returned. Of the respondents $96 \%$ had used Instagram daily, while $4 \%$ weekly. The questionnaire measured the frequency of using Instagram in searching for information on fashion trends, influencers followed, and fashion innovativeness.

To determine the sources of information on fashion available on Instagram a review of influencers was made. Firstly, using a focus group of fashion students and fashion experts a preliminary list of influencers significant for the Generation Z was drawn. Secondly, using a commercially available rating from Hypeauditor, the list was narrowed down by criteria presented in Table 1. The criteria used popularity expressed by number of followers and communication with audiences (engagement), as well as fashion topics content. 
Table 1: Fashion influencers used in the research

\begin{tabular}{|l|c|c|c|c|c|}
\hline Profile Name & Code & Followers('000) & Global Rank & Engagement & Fashion content \\
\hline Ariana Grande & ArG & 129800 & 8 & $1.44 \%$ & $66 \%$ \\
\hline Kylie Jenner & KJ & 115800 & 3 & $4.06 \%$ & $76 \%$ \\
\hline Gigi Hadid & GH & 43500 & 25 & $2.82 \%$ & $82 \%$ \\
\hline Lele Pons & LP & 28700 & 20 & $7.40 \%$ & $77 \%$ \\
\hline Amanda Cerny & AC & 22900 & 60 & $4.82 \%$ & $69 \%$ \\
\hline Emily Ratajkowski & ER & 19700 & 117 & $3.64 \%$ & $78 \%$ \\
\hline Millie Bobby Brown & MBB & 17600 & 40 & $12.92 \%$ & $76 \%$ \\
\hline Liza Koshy & LK & 17400 & 83 & $6.75 \%$ & $75 \%$ \\
\hline Chloe Grace Moretz & CGM & 15200 & 300 & $1.83 \%$ & $81 \%$ \\
\hline Hannah Stocking & HS & 14300 & 146 & $6.40 \%$ & $77 \%$ \\
\hline Chiara Ferragni & CF & 13500 & 244 & $2.59 \%$ & $88 \%$ \\
\hline Zoella & Z & 10700 & 258 & $5.05 \%$ & $83 \%$ \\
\hline Alissa Violet & AV & 8600 & 252 & $9.02 \%$ & $80 \%$ \\
\hline Ashley Graham & AG & 7500 & 679 & $2.42 \%$ & $73 \%$ \\
\hline Eva Gutowski & EG & 5600 & 677 & $5.87 \%$ & $87 \%$ \\
\hline Bethany Mota & BM & 5300 & 911 & $3.74 \%$ & $88 \%$ \\
\hline Negin Mirsalehi & NM & 5000 & 1128 & $3.31 \%$ & $92 \%$ \\
\hline Zorana Jovanovic & ZJ & 912 & 13590 & $2.17 \%$ & $98 \%$ \\
\hline Viktorija Loba & VL & 51 & 211490 & $5.15 \%$ & $73 \%$ \\
\hline Monika Potter & MP & 16 & 724150 & $5.91 \%$ & $75 \%$ \\
\hline
\end{tabular}

The influencers used in the research can be classified as: global celebrities in the entertainment and fashion industries ( $A r G, K J, E R, G H, A G, C G M, M B B$ ), global citizen influencers ( $Z, B M, E G, L P, H S, L K, A C, A V$, $C F, N M)$ and local influencers (ZJ, MP, VL). The following of influencers was measured on a scale from: 1-follower to 5-unaquainted with the influencer.

To measure fashion innovativeness two approaches were adopted. Firstly, a theoretical scale measuring domain-specific innovativeness for fashion goods, developed by Goldsmith and Hofacker [22], was used. The scale consists of six five-point Likert-type questions which ranged from "strongly disagree" (1) to "strongly agree" (5), with higher summary scores indicating higher innovativeness. Cronbach's alpha for the scale on the set of respondents was 0.745 , which suggest that the measures for the scale was internally consistent. From the scale a fashion innovativeness index was obtained, ranging from 1 (innovators) to 5 (laggards). The frequency of distribution of participants with index 1 was 19.6\%, index $2-28.9 \%$, index $3-27.8 \%$, index $4-19.6 \%$ and index $5-4.1 \%$. Due to the age group of the population the distribution of fashion innovativeness is visibly skewed towards fashion innovators. Secondly, panels with fashion trends for jeans were distributed. Jeans were chosen as a clothing object frequently used by the target group, which in the past decade has distinct trends. Fashion archives and future trend predictions from wgsn.com and juststyle.com were used to construct the panels. Respondents were asked to rate the trends from least fashionable to most fashionable. 


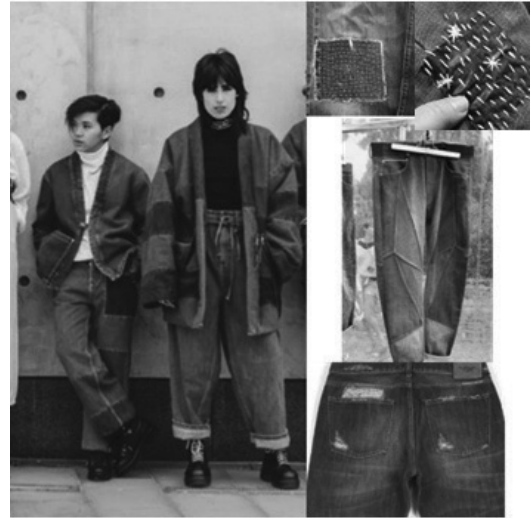

2020

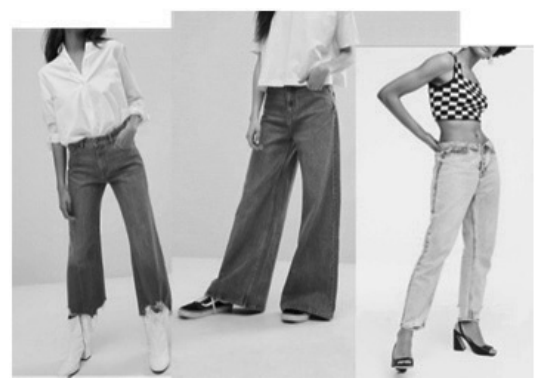

2018

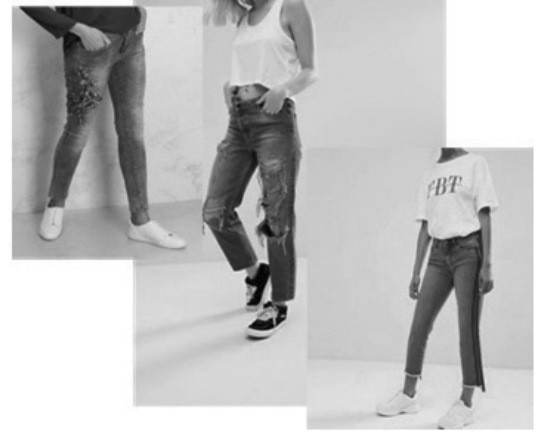

$2015 / 2017$

Figure 1: Jeans trend panels

\section{RESULTS}

As shown by their fashion innovativeness index the population used in the research consists of young, fashion conscious women. Therefore, it is not surprising that Instagram was frequently used for searching fashion trends. Of the examined sample $46 \%$ followed fashion trends on Instagram daily, $25 \%$ weekly, $7 \%$ monthly and $22 \%$ less than once a month. The frequency of following fashion trends differed with groups of different fashion innovativeness $\left(X^{2}=40,87\right.$, $d f=12, p=0,000$ ). As can be seen from Table 2, approximately $95 \%$ of fashion innovators use Instagram for viewing fashion trends daily or weekly, whereas with groups in the later stages of fashion diffusion process the frequency falls.

Despite the high index of fashion innovativeness, the respondents did not recognise of fashion trends for jeans. The trends for seasons 2015 to 2017 were ranked as most fashionable by $70.1 \%$ of respondents, while least fashionable by $13.4 \%$ of respondents. Current trends for the seasons were most often ranked as second, by $67.0 \%$ of respondents. Future trends were ranked as most fashionable by $11.3 \%$ of respondents, while least fashionable by $71.1 \%$ of respondents. Bear- ing in mind that the number of fashion innovators in a population follows the normal distribution and can be expected to be around $2.5 \%$, the recognition of fashion trends was relatively high.

To identify Instagrammers influencing fashion information search and fashion innovativeness a cluster analysis was conducted using the variables fashion innovativeness, information search, and following an influencer on Instagram. Variables were clustered using hierarchical cluster approach. Six clusters were obtained. The dendrogram depicting the clusters is shown in Figure 2. Variables are coded as per Table 1 , with addition of fashion innovativeness index (MI) and searching for fashion information over Instagram (Insta).

On the first level of the dendogram two branches can be seen. The second branch, comprasing of clusters 5 and 6 , contains all of the global citizen influencers. Cluster 6 contains the influencers trending at the time the research was conducted, while cluster 5 influencers who became famous through social media other than Instagram (e.g. Vine, Youtube etc.). These fashion influencers are typically involved in promoting high street fashion brands and have fashion

Table 2: Following fashion trends on Instagram by groups with different fashion innovativeness index

\begin{tabular}{lcccc}
\hline Fashion Innovativeness Index & \multicolumn{4}{c}{ Frequency of following fashion trends (\%) } \\
& Daily & Weekly & Monthly & Rarely \\
\hline 1-Innovators & 73.68 & 21.05 & 0.00 & 5.26 \\
2-Early adopters & 57.14 & 21.43 & 7.14 & 14.29 \\
3- Early majority & 48.15 & 33.33 & 3.70 & 14.81 \\
4-Late majority & 5.26 & 31.58 & 21.05 & 42.11 \\
5-Laggards & 0.00 & 0.00 & 0.00 & 100.00 \\
\hline
\end{tabular}




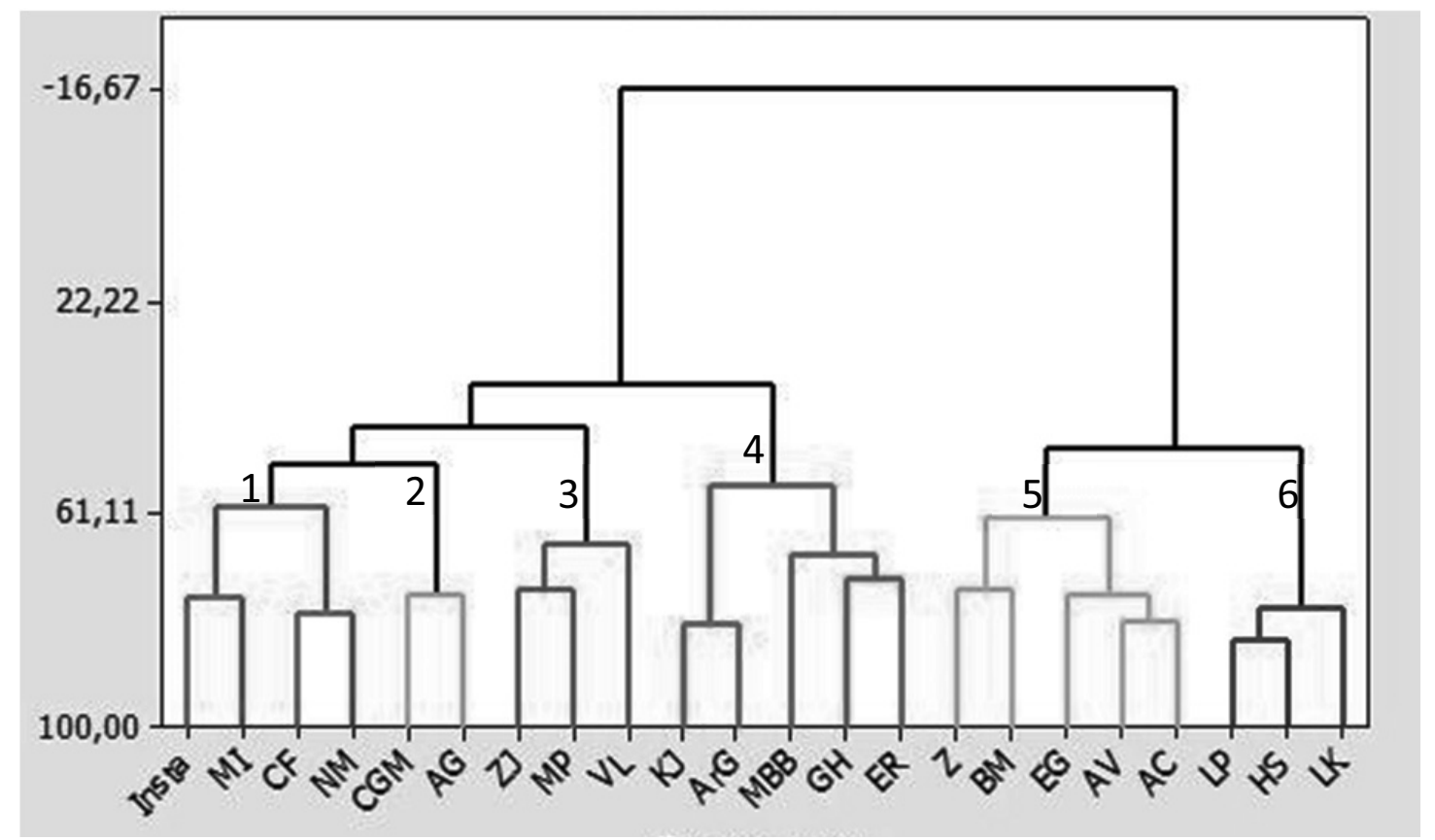

Figure 2: Dendrogram of fashion innovativeness, information search, and following an influencer on Instagram

content of around $80 \%$. Although they had a greater number of followers among the examined population (LP-14.4\% followes, HS-12.4\%, BM-9.3\%, LK, AV-6.2\%, AC, EG- $5.2 \%$, Z-3\%), their fashion content was not recognised. These influencers tipicaly use covert marketing strategies, while accent in the presentation is placed on other content, such as entertainment.

The second level dendogram also has two branches, of which cluster 4 included all of the global celebreties used in the research. These were influencers with the largest number of followers (ArG-22.7\%, ER-21.6\%, KJ -19.6\%, Gh 18.6\%). None the less, they have little influence on the fashion innovativeness and the search of fashion trends amongst the examined population.

The remaining three clusters 1,2 and 3 are the closest connected with information search for fashion trends and fashion innovativeness. The first cluster includes fashion bloggers, the second young celebrities relevant to Generation $\mathrm{Z}$ and the third local influencers.

To further examine the relationship a chi-square test was conducted between the following of an influencer and fashion innovativeness and information search, respectively. Table 3 shows the total number of followers of each Instagrammer (F), as well as the number of followers in groups who search for fashion information daily (FD) and with fashion innovators (FI) with the first and third cluster. No significant differences were found in the second cluster.

The first cluster includes fashion bloggers. The fashion content of their Instagram profiles is around $90 \%$. Although they are of a lower global rank, as seen in Table 1, and have fewer followers in the examined

Table 3: Chi-square test between the following of an influencer and fashion innovativeness and information search

\begin{tabular}{rrrcccccccc}
\hline \multirow{2}{*}{ Cluster } & \multirow{2}{*}{$\begin{array}{c}\text { Profile } \\
\text { code }\end{array}$} & & $F(\%)$ & \multicolumn{3}{c}{ Information search } & \multicolumn{4}{c}{ Fashion innovativeness } \\
\cline { 4 - 11 } & & FD (\%) & $X^{2}$ & df & p & Fl (\%) & $X^{2}$ & df & $\mathrm{p}$ \\
\hline 1 & CF & 9.3 & 18.2 & $\mathbf{2 5 . 6 7 1}$ & $\mathbf{1 2}$ & $\mathbf{. 0 1 2}$ & 15.8 & 19.241 & 16 & .256 \\
1 & NM & 7.2 & 15.9 & $\mathbf{2 1 . 2 2 1}$ & $\mathbf{1 2}$ & $\mathbf{. 0 4 7}$ & 21.1 & 24.029 & 16 & .089 \\
3 & ZJ & 14.4 & 18.2 & $\mathbf{2 6 . 4 6 3}$ & $\mathbf{1 2}$ & $\mathbf{. 0 0 9}$ & 26.3 & 19.801 & 16 & .229 \\
3 & MP & 15.5 & 22.7 & $\mathbf{2 5 . 9 0 0}$ & $\mathbf{1 2}$ & $\mathbf{. 0 1 1}$ & 31.6 & $\mathbf{3 0 . 7 9 4}$ & $\mathbf{1 6}$ & $\mathbf{. 0 1 4}$ \\
3 & VL & 15.5 & 25.0 & 13.141 & 12 & .359 & 21.1 & 23.209 & 16 & .108 \\
\hline
\end{tabular}


population (CF-9.3\%, NM-7.2\%) their specialised content makes them a popular source when searching for fashion information. In fact, with persons who search for fashion information daily they are significantly more popular than in the general population, as their number of followers doubles (CF - $18.2 \%$ of followers, NM - 15.9\%). This indicates that even though the young generation has greater fashion awareness in general, fashionistas are a distinct subculture. For this group Instagram presents a tool through which global trends can be distributed and followed daily. However, no significant differences were found regarding fashion innovativeness. Trends of wearing double denim in jeans were often seen in this cluster, Figure 3 , a) and b).

The third cluster consisted of local and regional citizen influencers (ZJ and MP) and local celebrities (VL). Due to language barriers their influence is localized. Although their global rankings are low, they are rated highest in the local communities. Their influence can also be seen from the parameter of engagement (Tab.1) which describes the level of communication with audiences, and is similar or higher than that of global celebrities. Similarly, to members of the first cluster they influenced the search for information and their popularity was higher among persons who search for fashion trends daily compared with the total population. Moreover, local citizen influencers from this group were the only ones where significant differences regarding fashion innovativeness were found. Fashion innovativeness is a complex issue that depends not only on the available information on trends, but also on various posed restraints, whether monetary or physical availability in local retail. Therefore, local citizen influencers who experience the same environmental and cultural cues exert greater influence on fashion innovativeness. Trends em- braced by them, even when they are past their prime in the fashion world, as seen in Figure 3, c), will have a greater influence on the local population.

\section{CONCLUSION}

New mass communication technologies, such as Instagram, present a hereby unparalleled channel for the distribution of fashion information, providing a possibility for a democratization in the fashion sector and a rapid diffusion of fashion. Influencers are the opinion leaders in this newly established fashion communication. This research investigated the influence of Instagram as a fashion information source and on the acceptance of fashion trends among Generation Z. While information on fashion on Instagram is available in both overt and covert presentations from many players, fashionistas remain a distinct subculture. They can easily recognize and follow influencers with relevant fashion content, whose popularity in the total Instagram universe is limited. However, local citizen influencers, who are subjected to the same real-life environmental and cultural cues in a certain community, exert greater influence on local fashions.

\section{REFERENCES}

[1] Ertas, Brashear, T.G., Kashyap, V., Musante, M.D. Donthu, N. (2009). A Profile of the Internet Shopper: Evidence from Six Countries, Journal of Marketing Theory and Practice, 17(3), 267-282.

[2] Arriaga, J., Andreu, D. Berlanga, V. (2017). Facebook in the low-cost fashion sector: the case of Primark, Journal of Fashion Marketing and Management: An International Journal, 21(4), 512-522.

[3] Choi, J., Park, J. (2006). Multichannel retailing in Korea, International Journal of Retail \& Distribution Management, 34(8), 577 - 596.

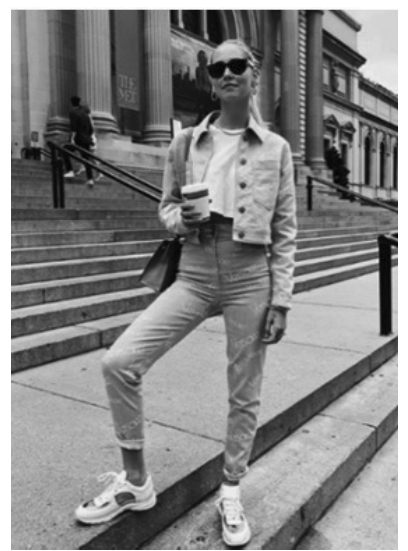

a) Chiara Ferragni, 7.09.2018.

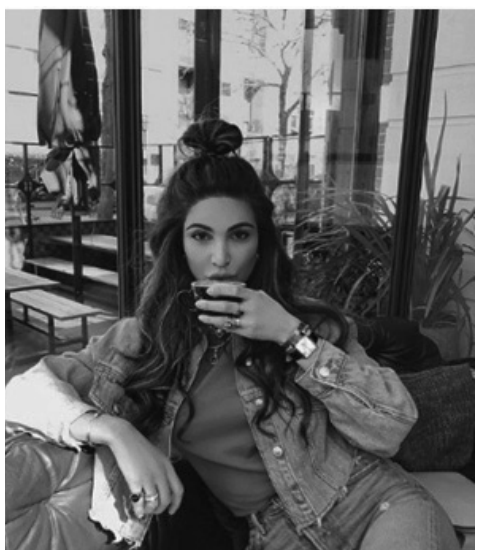

b) Negin Mirsalehi, 20.03.2018.

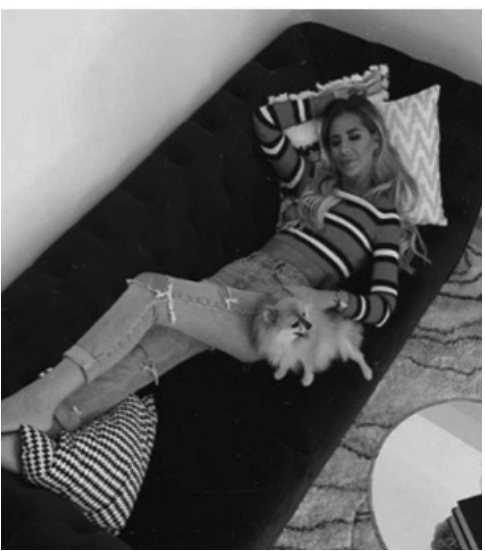

c) Zorana Jovanovic, 27.08.2018.

Figure 3: Jean trends worn by influencers on Instagram 
[4] What Is Instagram? Available from http: https:// instagram.com/about/2013 Accessed 2018-06-15.

[5] Instagram Users Available from https://www. statista.com/statistics/253577/number-ofmonthly-active-instagram-users/ Accessed 201807-10.

[6] Ruane, L., Wallace, E. (2013). Generation Y females online: insights from brand narratives, Qualitative Market Research: An International Journal, 16(3), $315-335$.

[7] Boardman, R., McCormick, H. (2018). Shopping channel preference and usage motivations: Exploring differences amongst a 50-year age span, Journal of Fashion Marketing and Management: An International Journal, 22(2), 270-284.

[8] Frings, G.S. (1987). Fashion from concept to consumer, Prentice Hall, New Jersey.

[9] Beaudoin, P., Moore, M.A., Goldsmith, R.E. (2000). Fashion leaders' and followers' attitudes toward buying domestic and imported apparel. Clothing and Textiles Research Journal, 18(1), 56-64.

[10] Flynn, L.R., Goldsmith, R.E., Eastman, J.K. (1996). Opinion leaders and opinion seekers: two new measurement scales, Journal of the Academy of Marketing Science, 24(2), 137-47.

[11] Gilly, M.C., Graham, J.L., Wolfinbarger, F.M., Yale, L.J. (1998). A dyadic study of interpersonal information search, Journal of the Academy of Marketing Science, 26(2), 83-100.

[12] Kowalczyk M. C., Pounders K. (2016). Transforming Celebrities through Social Media: The Role of Authenticity and Emotional Attachment, Journal of Product \& Brand Management, 25(4), 345-356.

[13] Brydges T., Sjöholm J. (2018). Becoming a personal style blogger: Changing configurations and spatialities of aesthetic labour in the fashion industry, International Journal of Cultural Studies, 1(1), 1-21.

[14] Abidin, C. (2016). Visibility labour: Engaging with Influencers' fashion brands and \#OOTD advertorial campaigns on Instagram, Media International Australia, 161(1), 86-100.

[15] Martensen, A., Schack, B. S., Zahid, L. A. (2018). How citizen influencers persuade their followers, Journal of Fashion Marketing and Management: An International Journal, 22(3), 335-353.

[16] Kusumasondjaja, S. (2019). Exploring the role of visual aesthetics and presentation modality in luxury fashion brand communication on Instagram,
Journal of Fashion Marketing and Management: An International Journal, 24(1), 15-31.

[17] Geissinger, A., Laurell, C. (2018). Tracing brand constellations in social media: the case of fashion week Stockholm, Journal of Fashion Marketing and Management: An International Journal, 22(1), 3548.

[18] Bonilla, M., Arriaga, J.L., Andreu, D. (2019). The interaction of Instagram followers in the fast fashion sector: The case of Hennes and Mauritz (H\&M), Journal of Global Fashion Marketing, DOI:1 $0.1080 / 20932685.2019 .1649168$

[19] Park, H., Burns, L.D., Rabolt N.J. (2007). Fashion innovativeness, materialism, and attitude toward purchasing foreign fashion goods online across national borders: The moderating effect of internet innovativeness, Journal of Fashion Marketing and Management, 11(2), 201-214.

[20] Chen, H. (2018). College-Aged Young Consumers' Perceptions of Social Media Marketing: The Story of Instagram, Journal of Current Issues \& Research in Advertising, 39(1), 22-36.

[21] Goldsmith, R.E. (2000). Characteristics of the heavy user of fashionable clothing, Journal of Marketing Theory and Practice, 8(4), 21-8.

[22] Goldsmith R.E., Moore, M.A., Beaudoin P. (1999). Fashion innovativeness and self-concept: A replication, Journal of Product\&Brand Management, 8(1), 7-18.

Rad primljen: 01.11.2020.

Rad prihvaćen: 15.11.2020. 